\title{
Time-limited protective effect of inhaled frusemide against aspirin-induced bronchoconstriction in aspirin-sensitive asthmatics
}

\author{
P. Sestini*, M.G. Pieroni*, R.M. Refini*, M. Robuschi**, \\ S. Spagnotto**, A. Vaghi+, S. Bianco ${ }^{++}$ \\ G. Gambaro**,
}

Time-limited protective effect of inhaled frusemide against aspirin-induced bronchoconstriction in aspirin-sensitive asthmatics. P. Sestini, M.G. Pieroni, R.M. Refini, M. Robuschi, G. Gambaro, S. Spagnotto, A. Vaghi, S. Bianco. CERS Journals Ltd 1994. ABSTRACT: Inhaled frusemide effectively prevents the bronchial obstructive response to allergens and to a number of nonallergic stimuli. In most of the experimental models in which it has been tested, the protective effect of frusemide has been evaluated for only a short time after administration. In aspirin-sensitive patients, acetylsalicylic acid causes an asthmatic reaction which typically lasts for $2 \mathrm{~h}$ or more after exposure. We investigated the presence and duration of the protective effect of inhaled frusemide against the bronchial response to aspirin in sensitive patients, using a specific inhalation challenge with lysine acetylsalicylate (LASA).

In the first study, eight subjects with aspirin-asthma underwent two bronchial challenges with a single dose of lysine acetylsalicylate administered through a jet nebulizer, after treatment with $\mathbf{4 0} \mathrm{mg}$ inhaled frusemide or placebo, according to a randomized, double-blind protocol. Forced expiratory volume in one second $\left(F_{E V}\right)$ was monitored for 120 min after challenge. In the second study in eight patients, the protocol was modified by the use of a dosimeter for delivery of lysine acetylsalicylate, by reducing the dose of lysine acetylsalicylate to avoid intense reactions, and by extending the follow-up to $4 \mathrm{~h}$.

In the first study, after placebo, $\mathrm{FEV}_{1}$ gradually decreased, reaching a maximum decrement of $39 \pm 3 \%$ at $120 \mathrm{~min}$. Inhaled frusemide exerted a significant protection at all time-points, although this activity appeared to decrease with time. In the second study, after placebo, inhaled lysine acetylsalicylate caused a gradual decrease in $\mathrm{FEV}_{1}$, which reached a maximum decrement at 180 min. Frusemide provided a significant protection in the first $90 \mathrm{~min}$ of the reaction; thereafter, FEV fell gradually to levels similar to placebo.

We conclude that inhaled frusemide effectively prevents the asthmatic reaction to lysine acetylsalicylate in aspirin sensitive patients, but this protective effect is limited in time.

Eur Respir J., 1994, 7, 1825-1829.
*Institute of Respiratory Diseases, University of Siena, Siena, Italy.

**Institute of Respiratory Diseases, University of Milan, Milan, Italy.

+Division of Pneumology, Ospedale di Garbagnate, Milan, Italy.

++Institute of Respiratory and Cardiovascular Diseases, Ospedale S. Raffaele, University of Milan, Milan, Italy.

Correspondence: P. Sestini

Institute of Respiratory Diseases

Viale Bracci 3

3100 Siena

Italy

Keywords:

Aspirin-induced bronchoconstriction

bronchial asthma

frusemide

Received: January 201994

Accepted after revision June 131994
Inhalation of frusemide and, to a lesser extent other loop diuretics, inhibits the bronchoconstriction induced by allergens and by several nonallergic stimuli, such as exercise, hypo- and hypertonic aerosols, cold air, metabisulphite and adenosine $[1,2]$. Although frusemide protects against the late asthmatic reaction up to $12 \mathrm{~h}$ after allergen exposure [3], the protective effect against ultrasonically-nebulized distilled water and sodium metabisulphite is relatively short-lived, lasting for $1-2 \mathrm{~h}[4,5]$. Bronchoconstriction induced by inhaled acetylsalicylic acid (ASA) in aspirin-sensitive asthmaticshas a relatively long time course, peaking around the second hour and usually lasting more than $4 \mathrm{~h}$ after exposure $[6,7]$. Previous observations indicating a protective effect of inhaled frusemide on aspirin-induced asthma have been limited to the initial phase of the response $[8$, 9]. In this paper, we report our preliminary observations [8], and a subsequent study conducted to verify them and to investigate the duration of the protective effect of frusemide on aspirin-induced asthma.

Materials and methods

\section{Patients}

We studied a total of 16 patients, with a clinical history of aspirin-induced asthma confirmed by a preliminary inhalation challenge with lysine acetylsalicylate (LASA) [10]. All the patients were in stable clinical condition, had a baseline forced expiratory volume in one second 
Table 1. - Patient characteristics - Study 1

\begin{tabular}{|c|c|c|c|c|c|c|c|}
\hline $\begin{array}{l}\text { Pat } \\
\text { No. }\end{array}$ & Sex & $\begin{array}{l}\text { Age } \\
\text { yrs }\end{array}$ & $\begin{array}{l}\text { Nasal } \\
\text { polyps }\end{array}$ & Atopy & $\begin{array}{l}\mathrm{FEV}_{1} \\
\% \text { pred }\end{array}$ & $\begin{array}{c}\mathrm{PD}_{30} \text { LASA } \\
\text { mg }\end{array}$ & Therapy \\
\hline 1 & $\mathrm{~F}$ & 50 & Yes & $\mathrm{Gr}$ & 87 & 5.2 & $\mathrm{f}, \mathrm{ib}, \mathrm{bcl}, \mathrm{t}$ \\
\hline 2 & M & 57 & Yes & - & 118 & 5.2 & $\mathrm{f}, \mathrm{ib}, \mathrm{bcl}$ \\
\hline 3 & $\mathrm{~F}$ & 46 & Yes & - & 69 & 5.2 & $\mathrm{f}, \mathrm{ib}, \mathrm{bcl}, \mathrm{cs}$ \\
\hline 4 & $\mathrm{~F}$ & 43 & No & - & 90 & 1.3 & $\mathrm{~s}$ \\
\hline 5 & $\mathrm{~F}$ & 42 & No & - & 100 & 2.6 & f. ip, bcl \\
\hline 6 & M & 72 & Yes & - & 63 & 5.2 & $\mathrm{~s}$ \\
\hline 7 & M & 35 & Yes & - & 53 & 3.9 & $\mathrm{f}, \mathrm{ip}, \mathrm{t}, \mathrm{bcl}$ \\
\hline 8 & $\mathrm{~F}$ & 63 & No & - & 100 & 5.2 & $\mathrm{~s}, \mathrm{bcl}$ \\
\hline
\end{tabular}

f: inhaled fenoterol; ib: inhaled ipratropium bromide; s: inhaled salbutamol; bcl: inhaled beclomethasone; t: oral theophylline; cs: oral steroids; Gr: grass pollen; $\mathrm{FEV}_{1}$ : forced expiratory volume in one second; F: female; M: male; LASA: lysine acetylsalicylate; $\mathrm{PD}_{30}$ : provocative dose producing a $30 \%$ fall in $\mathrm{FEV}_{1}$.

Table 2. - Patient characteristics - Study 2

\begin{tabular}{llcccccc}
\hline $\begin{array}{l}\text { Pat } \\
\text { No. }\end{array}$ & Sex & $\begin{array}{c}\text { Age } \\
\text { yrs }\end{array}$ & $\begin{array}{c}\text { Nasal } \\
\text { polyps }\end{array}$ & Atopy & $\begin{array}{c}\mathrm{FEV}_{1} \\
\% \text { pred }\end{array}$ & $\begin{array}{c}\mathrm{PD}_{20} \text { LASA } \\
\text { mg }\end{array}$ & Therapy \\
\hline 1 & $\mathrm{~F}$ & 25 & No & - & 102 & 4.0 & $\mathrm{~S}, \mathrm{t}, \mathrm{bcl}$ \\
2 & $\mathrm{~F}$ & 23 & No & $\mathrm{Dp}$ & 82 & 16.0 & $\mathrm{f}, \mathrm{ib}, \mathrm{bcl}$ \\
3 & $\mathrm{~F}$ & 64 & Yes & - & 83 & 1.0 & $\mathrm{t}, \mathrm{s}, \mathrm{cs}$ \\
4 & $\mathrm{~F}$ & 18 & Yes & Dp & 83 & 16.0 & $\mathrm{~s}$ \\
5 & $\mathrm{M}$ & 48 & No & - & 61 & 1.0 & $\mathrm{t}, \mathrm{ib}, \mathrm{f}, \mathrm{bcl}$ \\
6 & $\mathrm{M}$ & 73 & No & - & 48 & 2.0 & $\mathrm{~s}, \mathrm{ib}, \mathrm{bcl}$ \\
7 & $\mathrm{~F}$ & 60 & No & - & 79 & 1.0 & $\mathrm{t}, \mathrm{bcl}$ \\
8 & $\mathrm{~F}$ & 25 & Yes & Dp & 102 & 8.0 & $\mathrm{~s}$ \\
\hline
\end{tabular}

Dp: Dermatophagoides pteronyssinus. For further abbreviations see legend to table 1 .

$\left(\mathrm{FEV}_{1}\right)$ above $50 \%$ of predicted, and were free of respiratory infections for at least 6 weeks. All the patients were treated with inhaled $\beta_{2}$-stimulants on demand, and the majority were taking inhaled beclomethasone on a regular basis, in a dose range of $200-2,000 \mu \mathrm{g} \cdot \mathrm{day}^{-1}$. Two patients also required a low dose of oral prednisone to maintain clinical stability (tables 1 and 2). All treatments were withheld for at least $12 \mathrm{~h}$ before the challenge test, except for slow-release theophylline which was withheld for at least $24 \mathrm{~h}$ in advance [11]. Patients allergic to pollen were studied outside the pollen season. The study was conducted according to the ethical standards of our institution, requiring informed consent from each patient.

\section{Study design}

The study consisted of two parts, both of which were conducted according to randomized, double-blind protocols. Bronchial challenge with LASA was performed using two different techniques, which are progressive modifcations of the inhalation challenge originally described [10, 12, 13]. In a first group of patients (Study 1), we used a method of continuous aerosol generation with a jet nebulizer (Nebula, Markos, Monza, Italy) during tidal breathing inhalation for drug delivery. By appropriately combining the concentration of the solution and the time of nebulization, the amounts of LASA (Flectadol, Maggioni Winthrop Italia, Milan, Italy) progressively delivered to the mouth at $1 \mathrm{~h}$ intervals were $0.65 \mathrm{mg}(0.3 \mathrm{mg}$ if an intense reactivity was suspected), 1.2, 2.6, 5.6, 10.4, 20.8 and $41.6 \mathrm{mg}$, until a fall in $\mathrm{FEV}_{1}$ of $30 \%$ or more with respect to baseline was observed within $1 \mathrm{~h}$ of exposure.

The patients performed two bronchial challenges, with an interval of 7-10 days, using a single dose of LASA corresponding to the last cumulative dose administered in the preliminary test. Immediately before each challenge, they received $4 \mathrm{ml}$ of an aerosol containing either $40 \mathrm{mg}$ frusemide (Lasix, Hoechst, Frankfurt am Main, Germany) or placebo (the diluent), administered with a jet nebulizer (Nebula, Markos, Brescia, Italy) over a period of $20 \mathrm{~min}$. $\mathrm{FEV}_{1}$ was recorded before and after treatment and at 30, 60, 90 and 120 min after exposure to LASA. Clinical and anthropometric characteristics of the patients who participated in this part of the study are shown in table 1 .

In a second group of patients (Study 2) (table 2) the bronchial challenge was modified [14] using a Mefar dosimeter (Mefar, Bovezza, Italy) set to deliver $5 \mu \mathrm{l}$ of $180 \mathrm{mg} \cdot \mathrm{ml}^{-1}$ LASA (corresponding to $500 \mu \mathrm{g} \mathrm{ASA}$. puff $^{-1}$ ) during a deep breath from functional residual capacity (FRC) to total lung capacity (TLC), at intervals of $6 \mathrm{~s}$. $\mathrm{FEV}_{1}$ was obtained by integration of flows measured with a No. 3 Fleisch pneumotachograph (Fenyves \& Gut, Basel, Switzerland) 30 and $60 \mathrm{~min}$ after challenge. Doubling doses of LASA were progressively administered at $1 \mathrm{~h}$ intervals, starting from 1 $\mathrm{mg}(0.5 \mathrm{mg}$ if an intense reaction was suspected), until a decrease in $\mathrm{FEV}_{1}$ of $20 \%$ or more was observed, or the final dose of $64 \mathrm{mg}$ was reached. However, if after $1 \mathrm{~h} \mathrm{FEV}_{1}$ decreased by $15-20 \%$, administration of the 
subsequent dose of LASA was deferred for a further 30-60 min and was not given if the decrement in FEV reached $20 \%$ or more with respect to baseline in this time. $\mathrm{FEV}_{1}$ was recorded every $30 \mathrm{~min}$ for $4 \mathrm{~h}$, thereafter.

The rest of the study was conducted according to a protocol similar to Study 1, except that $\mathrm{FEV}_{1}$ was recorded every half hour up to 240 min after exposure and a third day of testing was added, in which the patients were treated with placebo and exposed to a placebo (50 $\mathrm{mg} \cdot \mathrm{ml}^{-1}$ lysine in saline), to check their clinical stability over the period of the test. The single dose of LASA used for challenge was the dose causing a decrease in $\mathrm{FEV}_{1}$ of $20 \%$ or more during the whole preliminary test, rather than $30 \%$ at $1 \mathrm{~h}$ used in the first study, to reduce the intensity of the reaction at subsequent times.

\section{Statistical analysis}

Analysis of variance was used to compare $\mathrm{FEV}_{1}$ with baseline at different time points [15]. Student's paired t-test was used for comparison of the two treatment groups at the same time-point [16]. The percentage of protection afforded by frusemide was computed using the formula: $(\mathrm{P}-\mathrm{F}) / \mathrm{P} \times 100$, where $\mathrm{P}$ and $\mathrm{F}$ are the percentage decrease in $\mathrm{FEV}_{1}$ with respect to baseline at the same time-point after placebo and frusemide, respectively. A p-value less than or equal to 0.05 was considered significant. Unless stated otherwise, the data are presented as means \pm SEM.

\section{Results}

\section{Study 1}

Baseline $\mathrm{FEV}_{1}$ was similar on both days of the study $(2.34 \pm 0.25 l$ and $2.41 \pm 0.24 l$ before placebo and frusemide, respectively), and was not modified by placebo or frusemide. After placebo, $\mathrm{FEV}_{1}$ was already significantly reduced $30 \mathrm{~min}$ after LASA, progressively decreasing to a minimum of $-39 \pm 3 \%$ at $120 \mathrm{~min}$. After frusemide, $\mathrm{FEV}_{1}$ was substantially unchanged with respect to baseline $30 \mathrm{~min}$ after exposure, gradually decreasing, thereafter, to a significantly lower value than after placebo, and reaching a minimum of $-24 \pm 7 \%$ at $120 \mathrm{~min}$ (fig. 1). The degree of protection afforded by frusemide was $52 \pm 19 \%$ at $30 \mathrm{~min}, 72 \pm 9 \%$ after $60 \mathrm{~min}$, $56 \pm 13 \%$ after $90 \mathrm{~min}$ and $37 \pm 14 \%$ after $120 \mathrm{~min}$.

\section{Study 2}

Since, in the previous study, the protection afforded by frusemide seemed to decrease with time, the protocol was modified to include further time-points. A control day was also included to exclude clinical instability during this longer period of observation. As shown in figure 2 , the patients remained stable during the control day for the whole period of observation. None showed changes of more than $10 \%$ with respect to baseline in this period.

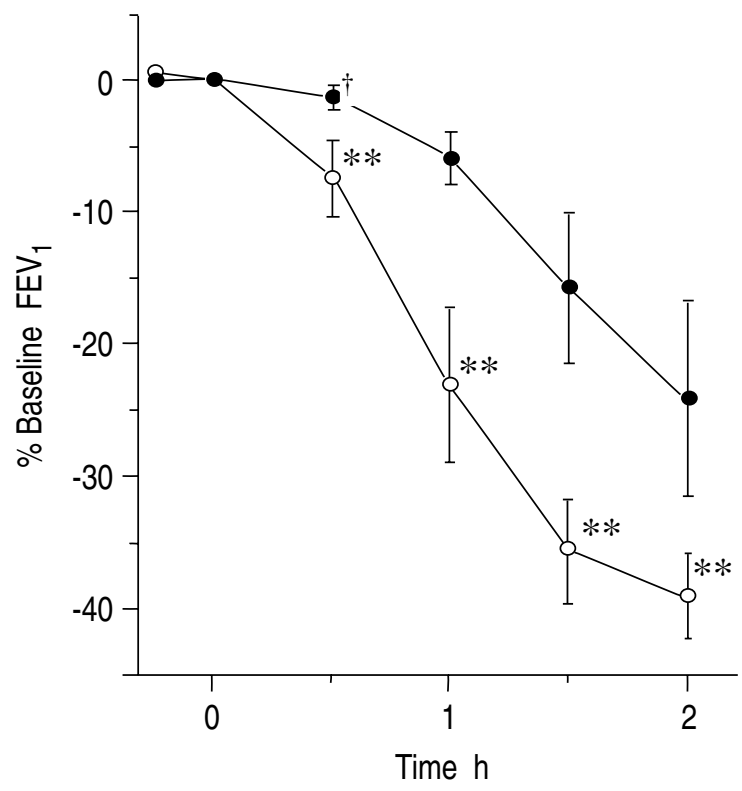

Fig. 1. - Study 1. Effect of inhaled frusemide on the bronchial obstructive response to a single dose of inhaled LASA $\left(\mathrm{PD}_{30}\right)$ in sensitive asthmatics, monitored for $2 \mathrm{~h}$. LASA: lysine acetylsalicylate; $\mathrm{FEV}_{1}$ : forced expiratory volume in one second; $\mathrm{PD}_{30}$ : provocative dose of LASA causing a $30 \%$ fall in $\mathrm{FEV}_{1}$. $-\mathrm{O}-$ : placebo; - frusemide; $\dagger$ : nonsignificant $v s$ baseline; $* *: \mathrm{p}<0.05 v s$ frusemide.

After placebo, $\mathrm{FEV}_{1}$ was significantly reduced $30 \mathrm{~min}$ after exposure to LASA and continued to decrease to $-20 \pm 3 \%$ with respect to baseline at $3 \mathrm{~h}$. Maximum individual $\mathrm{FEV}_{1}$ decrease during the test was $26 \pm 2 \%$ and occurred between 120 and 240 min after challenge in all the patients except one (table 2 patient No. 7) who had a peak at $30 \mathrm{~min}$ (mean $131 \pm 20 \mathrm{~min}$ ).

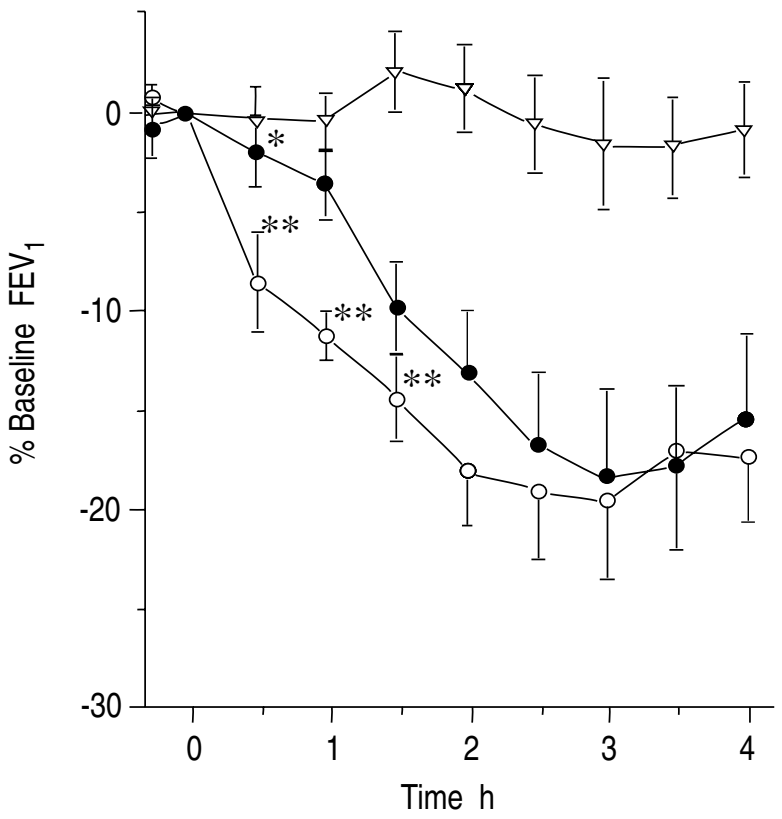

Fig. 2. - Study 2. Effect of inhaled frusemide on the bronchial obstructive response to a single dose of LASA $\left(\mathrm{PD}_{20}\right)$, monitored for $4 \mathrm{~h}$. $\mathrm{PD}_{20}$ : provocative dose of LASA producing a $20 \%$ fall in $\mathrm{FEV}_{1}$. ○- : placebo; - — : frusemide; $\longrightarrow$ - : control day. *: not significant $v s$ baseline; **: $\mathrm{p}<0.05 v s$ frusemide. For further abbreviations see legend to Figure 1. 
After frusemide, $\mathrm{FEV}_{1} 30$ and $60 \mathrm{~min}$ after LASA was not statistically different from baseline, but was significantly higher than at these time points and $90 \mathrm{~min}$ after placebo. Thereafter, however, $\mathrm{FEV}_{1}$ decreased to levels not significantly different from placebo, dropping by $19 \pm 4 \%$ with respect to baseline at $3 \mathrm{~h}$. The degree of protection afforded by frusemide was $93 \pm 12 \%$ at 30 $\mathrm{min}, 64 \pm 14 \%$ at $60 \mathrm{~min}, 45 \pm 23 \%$ at $90 \mathrm{~min}, 40 \pm 25 \%$ at $120 \mathrm{~min}, 19 \pm 16 \%$ at $150 \mathrm{~min}, 10 \pm 14 \%$ at $180 \mathrm{~min} \mathrm{de}-$ creasing to negative levels, thereafter. The maximum individual decrease in $\mathrm{FEV}_{1}$ during the test was $23 \pm 3 \%$, not significantly different from placebo.

\section{Discussion}

Our results indicate that inhaled frusemide signifcantly inhibits aspirin-induced asthma, but this effect is limited to the initial part of the reaction. The trend towards a decreasing protective effect of frusemide with time was already evident in the first study, but it was underestimated because of the short period of observation. The protective effect was probably more evident in that study because the higher dose of LASA used for challenge caused a stronger reaction during placebo, increasing the difference with respect to the reaction modified by frusemide. The short duration of the protective effect of frusemide was completely missed in another study, conducted without randomization and with a period of observation limited to $30 \mathrm{~min}$ [9]. Although, in practice, the bronchial response to LASA is normally evaluated 60 min after challenge, often terminating the reaction with an inhaled bronchodilator $[6,7,10,12,13,17]$, the time course of the reaction is known to be longer [6,7], and such a short observation period is unsuitable for evaluating the effect of pharmacological agents on the bronchial response to LASA.

Although limited in time, frusemide nevertheless provided very effective protection in the first hour after challenge, suggesting that it has a powerful interaction with the pathogenic mechanism of aspirin-induced asthma. These mechanisms are not yet fully understood, but it has long been suggested that they involve the cyclooxygenase inhibitory activity of aspirin and other nonsteroidal anti-inflammatory drugs [18, 19], which might cause a shift in the metabolism of arachidonic acid towards the production of bronchoconstrictor leukotrienes, possibly by removing a prostaglandin-mediated inhibitory mechanism [20-22]. This hypothesis was recently supported by the observation of increased urinary excretion of leukotrienes during aspirin-induced asthma [23-26], and by studies indicating that aspirin-induced asthma is effectively prevented by leukotriene-receptor inhibitors [27, 28], reviewed in [29]. Interestingly, recent studies indicate that frusemide may interact with leukotriene production in the bronchial mucosa in several experimental models in vitro and in vivo. In vitro, frusemide has been shown to inhibit the release of leukotriene-like activity from passively sensitized human lung [30], and to inhibit allergen-induced human airway smooth muscle contractions in a leukotriene dependent model [31] (and A. Sala, personal communication). In vivo, we have recently shown that inhaled frusemide inhibits the urinary excretion of leukotriene $\mathrm{E}_{4}\left(\mathrm{LTE}_{4}\right)$, which accompanies the early asthmatic reaction after allergen challenge [32]. Taken together, these data suggest that an inhibitory effect on the biosynthesis of leukotrienes might contribute to the protective effect of frusemide in aspirin-induced asthma.

An additional and possibly related hypothesis, is that inhaled frusemide might be acting by causing a short-lived enhancement of the local production of prostaglandins, as suggested in other situations in vitro [31] and in vivo [33, 34]. Inhaled prostaglandin E (PGE) has previously been reported to efficiently protect against aspirin-induced asthma [12], and might act by inhibiting mediator releasing cells [35], affecting leukotriene metabolism $[22,26]$, or simply counteracting the inhibitory effect of LASA.

The protective effect could be limited in time either because a different, frusemide-resistant mechanism of bronchoconstriction is operating during the second part of the response to aspirin, or because frusemide has fast local kinetics in the airways. The latter hypothesis is supported by the observation that the protective effect of inhaled frusemide on bronchoconstriction induced by ultrasonic mist of distilled water [4], and by sodium metabisulphite [5], also decreases rapidly in the first $2 \mathrm{~h}$ after treatment, and is no longer operating at $3 \mathrm{~h}$. These observations apparently contrast with the protective effect against the late allergic asthma reaction, which occurs beyond the expected time of activity of inhaled frusemide. However, the release of leukotrienes, as assessed by urinary excretion, has a different time course in allergen-induced reactions than in ASA-induced asthma. In allergic reactions, it is limited to the first period after allergen exposure, and there is no evidence of leukotriene release during the late response $[25,36]$. The release of leukotrienes during the early asthmatic response to allergen may cause both transient bronchoconstriction and the development of the subsequent late reaction, possibly by increasing bronchial hyperreactivity [37], and by promoting the influx of inflammatory cells into the airways [38]. Frusemide may block both these event, by inhibiting the release of leukotrienes and other mediators occurring whilst it is still active in the airways. In aspirin-induced asthma, the increased production of leukotrienes lasts much longer, and closely parallels the asthmatic reaction [23, $25,39]$. Since a late reaction does not occur in this condition [7], the limited duration of the effect of frusemide may be explained by the simple fact that leukotriene release in this case lasts longer than the activity of the drug.

In conclusion, our results indicate that inhaled frusemide inhibits aspirin-induced asthma, and that its effectiveness is limited by the relatively short duration of its local effect. The hypothesis that this protective effect is mediated by the inhibition of leukotriene production in the bronchi requires experimental verification in further studies.

Acknowledgements: The authors are indebted to $\mathrm{H}$. Ampt for reviewing the manuscript. 


\section{References}

1. Bianco S, Pieroni M, Refini R, Robuschi M, Vaghi A, Sestini P. Inhaled loop diuretics as potential new antiasthma drugs. Eur Respir J 1993; 6: 130-134.

2. Barnes PJ. Diuretics and asthma. Thorax 1993; 48: 195-196.

3. Bianco S, Pieroni M, Refini R, Rottoli L, Sestini P. Protective effect of inhaled furosemide on allergeninduced early and late asthmatic reactions. $N$ Engl $J$ Med 1989; 321: 1069-1073.

4. Sestini P, Pieroni M, Refini R, Vaghi A, Vagliasindi M, Bianco $S$. Time course of the protective effect of inhaled furosemide on $\mathrm{UNH}_{2} \mathrm{O}$-induced bronchoconstriction. Eur Respir J 1991; 3: 237s.

5. Yeo C, O'Connor BJ, Chen-Worsdell M, Barnes PJ, Chung KF. Protective effect of loop diuretics, piretanide and frusemide, against sodium metabisulphiteinduced bronchoconstriction in asthma. Eur Respir $J$ 1992; 5: 1184-1188.

6. Bianco S. Asthme et médicaments anti-inflammatoires non stéroidiens. In: Charpin J, ed. Allergologie. 2nd edn. Paris, Flammarion, 1986: pp. 683-693.

7. Phillips GD, Foord R, Holgate ST. Inhaled lysineaspirin as a bronchoprovocation procedure in aspirinsensitive asthma: its repeatability, absence of a late-phase reaction, and the role of histamine. J Allergy Clin Immunol 1989; 84: 232-241.

8. Robuschi M, Gambaro G, Spagnotto S, Vaghi A, Petrigni G, Bianco S. Prevention of aspirin (ASA)induced bronchoconstriction by inhaled furosemide (F). Eur Respir J 1989; 2: 790s.

9. Vargas FS, Croce M, Teixeira L.R, Terra-Filho M, Cukier A, Light RW. Effect of inhaled furosemide on the bronchial response to lysine-aspirin inhalation in asthmatic subjects. Chest 1992; 102: 408-411.

10. Bianco S, Robuschi M, Simone P. Aspirin-induced tolerance in aspirin-asthma detected by a new challenge test. IRCS J Med Sci 1977; 5: 129.

11. Chai 11, Farr RS, Froelich LA, et al. Standardization of bronchial inhalation challenge procedures. $J$ Allergy Clin Immunol 1975; 56: 323-327.

12. Pasargiklian M, Bianco S, Allegra L, et al. Aspects of bronchial reactivity to prostaglandin and aspirin in asthmatic patients. Respiration 1977; 34: 79-91.

13. Bianco S, Robuschi M, Petrigni G. Aspirin sensitivity in asthmatics (letter). $B r$ Med $J$ 1981; 282: 116.

14. Melillo G, Padovano A, Masi C, Melillo E, Cocco G. Aspirin-induced asthma and bronchial hyperresponsiveness. Allergia et Immunologia 1991; 23: 423-426.

15. Dunnet CW. New tables for multiple comparison with a control. Biometrics 1964; 20: 482-491.

16. Snedecor GW, Cochran WG. In: Statistical Methods. 7th edn. Ames, Iowa State University Press, 1980.

17. Dahlén B, Zetterström O. Companson of bronchial and per oral challenge with ASA in ASA-sensitive asthmatics. Eur Respir J 1990; 3: 527-534.

18. Szczeklik A, Gryglewsky RJ, Gzerniawska-Mysik G. Relationship of inhibition of prostaglandin biosynthesis by analgesics in aspirin-sensitive asthma patients. $\mathrm{Br}$ Med J 1975; 1: 67-69.

19. Settipane GA. Adverse reactions to aspirin and related drugs. Arch Intern Med 1981; 141: 328-332.

20. Szczeklik A. Asthme, aspirine et leukotriènes. Bull Eur Physiopathol Respir 1983; 19: 531-538.

21. Ortolani C, Mirone C, Fontana A, et al. Study of medi- ators of anaphylaxis in nasal wash fluids after aspirin and sodium metabisulfite nasal provocation in intolerant rhinitic patients. Ann Allergy 1987; 559: 106-112.

22. Szczeklik A. The cyclo-oxygenase theory of aspirininduced asthma. Eur Respir J 1990; 3: 588-593.

23. Christie PE, Tagari P, Ford-Hutchinson AW, et al. Urinary leukotriene $\mathrm{E}_{4}$ after lysine-aspirin by inhalation in asthmatic subjects. Am Rev Respir Dis 1992; 146: $1531-1534$.

24. Knapp HR, Krzysztof S, Fitzgerald GA. Increased excretion of leukotriene $\mathrm{E}_{4}$ during aspirin-induced asthma. $J$ Lab Clin Med 1992; 119: 48-51.

25. Kumlin M, Dahlén B, Björk T, Zetterström O, Granström $\mathrm{E}$, Dahlén $\mathrm{S}$. Urinary excretion of leukotriene $\mathrm{E}_{4}$ and 11-dehydro-thromboxane $\mathrm{B}_{2}$ in response to bronchial provocations with allergen, aspirin, leukotriene $\mathrm{D}_{4}$ and histamine in asthmatics. Am Rev Respir Dis 1992; 146: 96-103.

26. Sladek K, Szczeklik A. Cysteinyl leukotrienes overproduction and mast cell activation in aspirin-provoked bronchospasm in asthma. Eur Respir J 1993; 6: 391-399.

27. Christie PE, Smith CM, Lee T. The potent and selective sulfidopeptide leukotriene antagonist, SK\&F 104353 inhibits aspirin-induced asthma. Am Rev Respir Dis 1991; 144: 957-958.

28. Dahlén B, Kumlin M, Margolskee DJ, et al. The leukotriene-receptor antagonist MK-0679 blocks airway obstruction induced by inhaled lysine-aspirin in aspirin-sensitive asthmatics. Eur Respir J 1993; 6: $1018-1026$.

29. Lee TH, Christie PE. Leukotrienes and aspirin-induced asthma. Thorax 1993; 48: 1189-1190.

30. Anderson SD, Wey H, Temple DM. Inhibition by furosemide of inflammatory mediators from lung fragments. N Engl J Med 1991; 234: 131.

31. Pavord 1, Holland E, Baldwin D, Tattersfield A, Know A. Frusemide and allergen-induced contractions of passively sensitized human bronchi: evidence of a role for prostaglandin $\mathrm{E}_{2}$. Thorax 1992; 47: 895.

32. Sala A, Arnetti L, Sestini P, Bianco S, Folco GC. Effect of furosemide on urinary $\mathrm{LTE}_{4}$ in asthmatic patients. Eur Respir J 1993; 6: 493s.

33. Pavord ID, Wisniewski A, Tattersfield AE. Inhaled frusemide and exercise-induced asthma: evidence of a role for inhibiting prostanoids. Thorax 1992; 47: 797800.

34. Polosa R, Rajakkulasingam K, Prosperini G, Holgate ST. Cyclo-oxygenase inhibition modulates the change in bronchial reactivity to methacholine with inhaled frusemide in normal subjects. Thorax 1992; 47: 853.

35. Pavord ID, Wong CS, Williams J, Tattersfield A. Effect of inhaled prostaglandin $\mathrm{E}_{2}$ on allergen-induced asthma. Am Rev Respir Dis 1992; 148: 87-90.

36. Manning B, Rokach J, Malo J, et al. Urinary leukotriene $\mathrm{E}_{4}$ levels during early and late asthmatic responses. $J$ Allergy Clin Immunol 1990; 86: 211-220.

37. O'Hickey SP, Hawksworth RJ, Fong CY, Arm JP, Spur BW, Lee T. Leukotrienes $\mathrm{C}_{4}, \mathrm{D}_{4}$ and $\mathrm{E}_{4}$ enhance histamine responsiveness in asthmatic airways. Am Rev Respir Dis 1991; 144: 1053-1057.

38. Laitinen LA, Laitinen A, Haatela T, Vilkka V, Spur BW, Lee TH. Leukotriene $\mathrm{E}_{4}$ and granulocytic infiltration into asthmatic airways. Lancet 1993; 341: 989-990.

39. Christie PE, Tagari P, Ford-Hutchinson AW, et al. Urinary leukotriene $\mathrm{E}_{4}$ concentrations increase after ASA challenge in ASA-sensitive asthmatic subjects. Am Rev Respir Dis 1991; 143: 1025-1029. 